\title{
A Review of Corporate Social Responsibility and Its Relationship with Customer Satisfaction and Corporate Image
}

\author{
Bruce Emmanuel1*, Owusu-Ansah Priscilla² \\ ${ }^{1}$ School of Management and Economics, University of Electronic Science and Technology of China, Chengdu, China \\ ${ }^{2}$ Centre for West African Studies, University of Electronic Science and Technology of China, Chengdu, China \\ Email: ^kinbuki100@outlook.com
}

How to cite this paper: Emmanuel, B., \& Priscilla, O.-A. (2022). A Review of Corporate Social Responsibility and Its Relationship with Customer Satisfaction and Corporate Image. Open Journal of Business and Management, 10, 715-728.

https://doi.org/10.4236/ojbm.2022.102040

Received: September 26, 2021

Accepted: March 6, 2022

Published: March 9, 2022

Copyright $\odot 2022$ by author(s) and Scientific Research Publishing Inc. This work is licensed under the Creative Commons Attribution International License (CC BY 4.0).

http://creativecommons.org/licenses/by/4.0/ (c) (i) Open Access

\begin{abstract}
The purpose of this paper is to review the effectiveness of Corporate Social Responsibility (CSR) and its relationship with customer satisfaction (CS), corporate image (CI), customer loyalty (CL), and market value performance (MVP). Corporate Social Responsibility (CSR) plays a significant role in enhancing corporate reputation and image. The study adopted secondary data, basically from previous related studies, books, and reports. The study concluded that CSR would serve as a strategic initiative for firms to engage customers and serve other stakeholders' interests. Again, the study found that CSR is effective for brand awareness, customer satisfaction, and market performance. The study will contribute to the body of knowledge on CSR, by expanding the boundaries of CSR as a business strategy by firms. Moreover, this study will enable industry players to make sound policies and strategies that could enhance corporate image. The study, therefore suggests that firms should integrate CSR strategy into their operations. The study discussed the limitations and suggests future research directions.
\end{abstract}

\section{Keywords}

Corporate Social Responsibility, Customer Satisfaction, Corporate Image, Corporate Reputation, Customer Loyalty

\section{Introduction}

To respond to the environment, most companies have embarked on corporate social responsibility (CSR) to address societal issues and to meet customers and stakeholder expectations (Pearce \& Doh, 2005; Weber, 2008). The World Bank 
defines CSR as "the commitment of business to contribute to sustainable economic development working with employees, their families, the local community and society to improve the quality of life in a way that both good for business and development".

Companies focusing on CSR activities in their entire business operations gain a competitive advantage and produce environmentally friendly products and services. A business with CSR contributes to shareholders' wealth and builds a strong company's reputation (Capozzi, Gregg, \& Howe, 2010). In particular, the implementation of CSR creates customer satisfaction and stakeholders' commitment (Maignan \& Ferrell, 2004). Also, CSR has become an avenue for business to enhance their relationship with customers. According to Manhas \& Tukamushaba (2015), the service experience with CSR influences consumers' evaluation and satisfaction. As a result, the product and service experience through CSR create repeat purchase by customers leading to loyalty and customer satisfaction. In modern business, we observe most firms in different industries such as manufacturing, agricultural, mining, telecommunications etc., have embarked on CSR strategy to attract customers and enhance firms' image and reputation. For instance, studies have shown that telecommunication companies have embarked on CSR to give back to the society. Other businesses also use CSR to address societal issues and to enhance corporate image (Harun et al., 2020).

Scholars have been examined to establish the relationship between corporate social responsibility (CSR) and customer satisfaction (Bhatti et al., 2018; Mensah et al., 2017). According to Alam \& Rubel (2014), CSR is deemed as a strategic weapon to ensure the existence of the company. For instance, Yazid (2020) found that activities of CSR have a direct relationship with the goodwill of existing employees and firms' image. Recent observations by Lee \& Yoon 2018; Yu et al. (2020), confirmed that CSR enhances corporate reputation and customer retention. Mohr et al., (2001) also observed that CSR positively influences brand image, customer loyalty and customer satisfaction.

Other scholars have conducted reviews on CSR and corporate image supported by numerous academic journals and conference proceedings. Latapí Agudelo et al. (2019) review the history and evolution of corporate social responsibility. Velte (2021) also uses meta-analyses to review CSR. In this study, we argue from the relationships CSR has with customer satisfaction, customer image and customer loyalty.

The main objective of this study was to review the relationship and influence between the corporate social responsibility concept on customer satisfaction and corporate image. The paper identifies the importance of corporate social responsibility in organizations as a business strategy. Thus, seeks to develop a critical review of the effects of corporate social responsibility on organizations. The study reviewed customer satisfaction, company image, customer loyalty and market value performance effects and its relationship with corporate social responsibility. Moreover, the study summarizes the discussion and conclusion with future research directions. The review provides useful information for practition- 
ers, researchers, and regulators in marketing field.

\section{Literature Review}

\subsection{Corporate Social Responsibility (CSR)}

Many terms have been interchangeably used for CSR such as stakeholder theory, corporate philanthropy, sustainability development, social marketing, corporate citizenship, corporate social performance. The concept of Corporate Social Responsibility (CSR) emphasized the importance of incorporating societal interests into business operations. CSR can be viewed from the ethical and philanthropic dimensions. The ethical dimension focused on the firm's responsibility and its legal obligation whiles philanthropy dwells on activities promoting the welfare of human beings. In this regard, companies have embarked on effective CSR initiatives to gain competitive advantage, being socially responsible to their stakeholders and enhance performance (Mohr et al., 2001; Suki et al., 2016). Avram \& Avasilcai (2014) established that CSR dimension is a way of addressing societal issues.

To explain further, Frederick (1983) suggested that CSR is a requirement for firms to manage and oversee the operation of an economic system that meets societal expectations. That means the production and the activities of firms must improve the socio-economic welfare. Recently, the customer service experience is evaluated based on CSR and therefore has a positive and negative influence on the company. The positive outcomes result in consumers' purchase intentions. Similarly, empirical evidence and theories suggested that initiatives of CSR activities affect consumers' evaluation, customer satisfaction and loyalty (Agyabeng-Mensah et al., 2020).

Scholars have confirmed that management and employees support for the CSR initiatives (Crane et al., 2008; Angelia \& Suryaningsih, 2015). Que et al., 2019; Brown \& Forster (2013) established that corporate social responsibility practice motivates manager's operations efficiently and business practices; for example, Darus, F. et al. (2013) also illustrated the effect of CSR on stakeholders and a key to mediating role to financial performance. Their research findings showed that philanthropical activities have positive effects on customer loyalty and employee retention. Similarly, Angelia \& Suryaningsih (2015) examined the CSR customer satisfaction relationship and concluded that CSR initiatives have a direct positive effect on both customer satisfaction and brand equity of a company.

\subsection{Corporate Social Responsibility and Customer Satisfaction (CS)}

One of the significant theories and practices in marketing is customer satisfaction and a driver of firm long-term profitability and market value (Darus et al., 2013). The relationship between customer satisfaction and CSR has been variously explored and defined by different management scholars. According to Luo \& Bhattacharya (2006), customer satisfaction in the long term has an effect 
on the corporate image.

In another related study, Phillips et al. (2019) revealed that CSR had a significant on value creation, customer satisfaction and a firm's sustainability. Customers are more addicted and loyal to the companies with CSR strategies (Lee et al., 2019). In their current study, Lee et al. (2019) modified pyramid framework was employed in the airline context and suggested CSR initiatives for the airline industry for customer satisfaction. A study by Islam et al. (2021), confirmed that corporate social responsibility initiatives are significantly and positively associated with corporate reputation, customer satisfaction, and customer trust. corporate reputation, customer satisfaction, and customer trust. The study further revealed that corporate social responsibility initiatives lead to high customer satisfaction and loyalty. This re-affirmed that companies with CSR strategies stand to enjoy better competitive edge over the others in the same industry. Latif et al. (2020) findings show positive impact on the organization's image, and more desirable customer behaviors in the context of hotel industry. Similar research by Ali (2018) confirmed corporate reputation and customer satisfaction as determining factors of corporate social responsibility. A further finding from the study shows customer loyal as a mediating role of CSR and customer satisfaction and corporate image. Other scholars (Luo \& Bhattacharya, 2006; Sen \& Bhattacharya, 2001) also noted that CSR has a significant positive relationship with customer satisfaction. Additionally, Mousiolis \& Zaridis (2014) observed that CSR initiatives positively affect customer-company identification and customer satisfaction.

On the contrary, Lee \& Kim, 2017; Hassan et al., (2013) argued that CSR has no direct impact on customer satisfaction. A study by Alrowais et al. (2020) also indicated CSR has relationship with customer awareness and satisfaction relations but does not have significant effects on experience customer service and customer loyalty in the hotel industry context.

\subsection{CSR and Corporate Image (CI)}

The brand image and reputation of a firm can be achieved through the activities of corporate social responsibility (Agyabeng-Mensah et al., 2020). Kotler \& Barich (1991) explained the term "image" as "the sum of beliefs, attitudes, and impressions that a person or group has of an object". The object, on the other hand, may be a company, product, brand, place, or person. Added to the above, Keller, (2003) also defined brand image as customers perceptions on brand evidenced by brand associations.

Previous studies have established the relationship between CSR and corporate image and brand loyalty; for example. Chung et al. (2015) examined the effects of CSR on customer satisfaction and corporate image. The study revealed that dimensions of CSR positively affect brand image, customer loyalty, and satisfaction. Organizations build image through reputation gained from the customers. The role of image plays a significant role in building a corporate reputation (Luo \& Bhattacharya, 2006). Customers' perception about a particular organization 
provides identity and therefore makes him/her choose the company anytime (Del-Castillo-Feito et al., 2019). In line with this, Ali et al. (2021) confirmed that company's image has a direct effect on the company's reputation. Similarly, Suki et al. (2016) also noted the positive impact of CSR on corporate image, customer satisfaction, and loyalty. In the hospitality context, Mohammed \& Rashid (2018) indicated that hotels with CSR strategy have good brand image and build better customer relationships. The findings from Arıkan \& Güner (2013) also observed that CSR dimensions build brand equity and image.

Added to the above, Aminudin (2013) also illustrated the significant effect of CSR on brand image, customer satisfaction and employee retention. Finally, Boateng \& Okoe (2015) found that CSR strategy influences consumer attitude and behavioral response, brand performance and customer satisfaction.

\subsection{CSR and Customer Loyalty (CL)}

The feeling that customers experience in relation to purchasing a product or service generates loyalty and is considered as one of the significant factors for a firm's survival and growth (Lemon et al., 2002). Oliver (1980) defined customer loyalty as "a deeply held commitment to rebuy or patronize a preferred product or service consistently in the future, despite situational influences and marketing efforts having the potential to cause switching behavior". Customer retention builds customer loyalty and satisfaction. Therefore, dimensions of CSR activities are means of building customer loyalty and corporate reputation. From the perspective of marketing, CSR is beneficial in building customer relationships and retention thereby creating loyalty in the long term. The dimensions of corporate social responsibility have a relationship with customer satisfaction and customer loyalty (Bhatti et al., 2018). Thus, building and retaining customers are recently been focused on by firms and CSR plays a mediating role. Corporate social responsibility has been linked to having effects on brand awareness and customer loyalty (Singh \& Misra, 2021).

To be specific, Lee \& Kim, (2017) indicated that CSR is a determinant factor for enhancing the company image and customer loyalty. According to Lee et al. (2019), CSR act as a mediating role in creating customer loyalty and corporate image in the context of the airplane industry. The study concluded that CSR positively influences consumers' behavioral intention hence leading to customer loyalty and satisfaction. In addition, Yusof et al. (2015) also observed that CSR has a positive effect on customer retention and loyalty. The empirical observation of Alam \& Rubel (2014) confirms that CSR has a positive relationship with customer satisfaction and loyalty. Suki et al. (2016) claimed that effective CSR activities build long-term trust and loyalty and improve the overall performance of the firm in the pharmaceutical industry.

Furthermore, Yoo et al. (2015) also noted that higher customer satisfaction results in customer loyalty. Nyadzayo \& Khajehzadeh (2016) confirm in their study that customer satisfaction is the important determinant of customer loyal- 
ty. Thus, if a customer is satisfied with a product or services of an organization, repeat purchase occurs. Consequently, customer loyalty has significant relationship with customer satisfaction in the telecom industry (Rychalski \& Hudson, 2017). In effect, if a customer is satisfied, it breeds customer trust, retention, and repeat purchase intention, therefore, satisfaction is a determining element of customer loyalty. In the banking industry, Muflih, (2021). Bukhari et al., 2020; Harun et al., 2020 also indicated that CSR directly and positively impacts loyalty. Finally, Reza et al. (2020) noted a positive significant association with customer loyalty in the hotel industry context.

\subsection{CSR and Market Value Performance (MVP)}

Values are created through sustainability. CSR activities help in achieving value creation through the link between sustainability and core business (Luo \& Bhattacharya, 2006). In this sense, employees are motivated and enhanced to work toward achieving the firm's objectives through CSR initiatives. Thus, increasing the firm market value and financial performance (Angelia \& Suryaningsih, 2015; Akben-Selcuk, 2019). Majority of the studies have confirmed the impact of CSR initiatives on the impact of firms' market value, for example, Sharma (2020) find out in their study that CSR activities have a great impact on the firms' market value in the banking context. The study used CSR score and annual reports with pooled ordinary least squares analysis model and was revealed that the financial performance of firms is influenced by the size and capital structure.

Similarly, (Mittal \& Sandhu, 2018; Jackson \& Hua, 2009) examined the CSR activities relationship and concluded that CSR activities positively and significantly affect both market value and financial performance, brand image and customer retention. In the banking context, studies proved that CSR positively affects market value performance. A study by Oyewumi et al. (2018) examined the influence of customer satisfaction on firm market value and revealed that organizations with low innovativeness capability reduces customer satisfaction levels and affect market value. The study demonstrated that CSR initiatives positively influence organizational market value and financial performance. This result was based on the effects of CSR initiatives on Nigeria's banking sector. Furthermore, Angelia \& Suryaningsih (2015) conducted a related study for the Indonesia Stock Exchange. The study examined the effect of environmental performance and CSR disclosure on financial performance and market value. The study used seventeen (17) companies and the results established that environmental performance and corporate social responsibility (CSR) disclosure simultaneously had a significant effect on ROA and ROE. Yu et al. (2020) used global index and CSR sub-index model based on global reporting initiative GRE, resource-based view initiative, and global environmental management initiative in their study and found that environmental dimension of CSR is a significant factor of corporate strategy and have a relationship with market value performance.

In accordance with García-Madariaga \& Rodríguez-Rivera, (2017) findings, 
CSR initiatives affect stakeholders and relate positively to market value and financial performance. Recently, Nyeadi et al. (2018) revealed that CSR has a positive impact on market value and financial performances in the extractive industry. Mitra (2021) also added that corporate social responsibility has both a positive and significant impact on firm performance. However, other studies (Mittal \& Sandhu, 2018) have shown that CSR has no direct impact on the market value.

\section{Methodology}

The study adopted exploratory type of research and a specific qualitative research method approach. Qualitative research method aid in establishing a developing relationship between variables in research without variable quantifications (Goundar, 2012). The study reviews corporate social responsibility and its effects on customer satisfaction, customer loyalty, corporate image and reputation and market value performance. The study adopted secondary data and collected data from credible sources such as internationally recognized books, accredited journals, and recognized and credible international media reports for reliable analysis. Figure 1 and Table 1 below depict the procedural flow of getting the relevant data for the study.

\section{Problem Conceptualization}

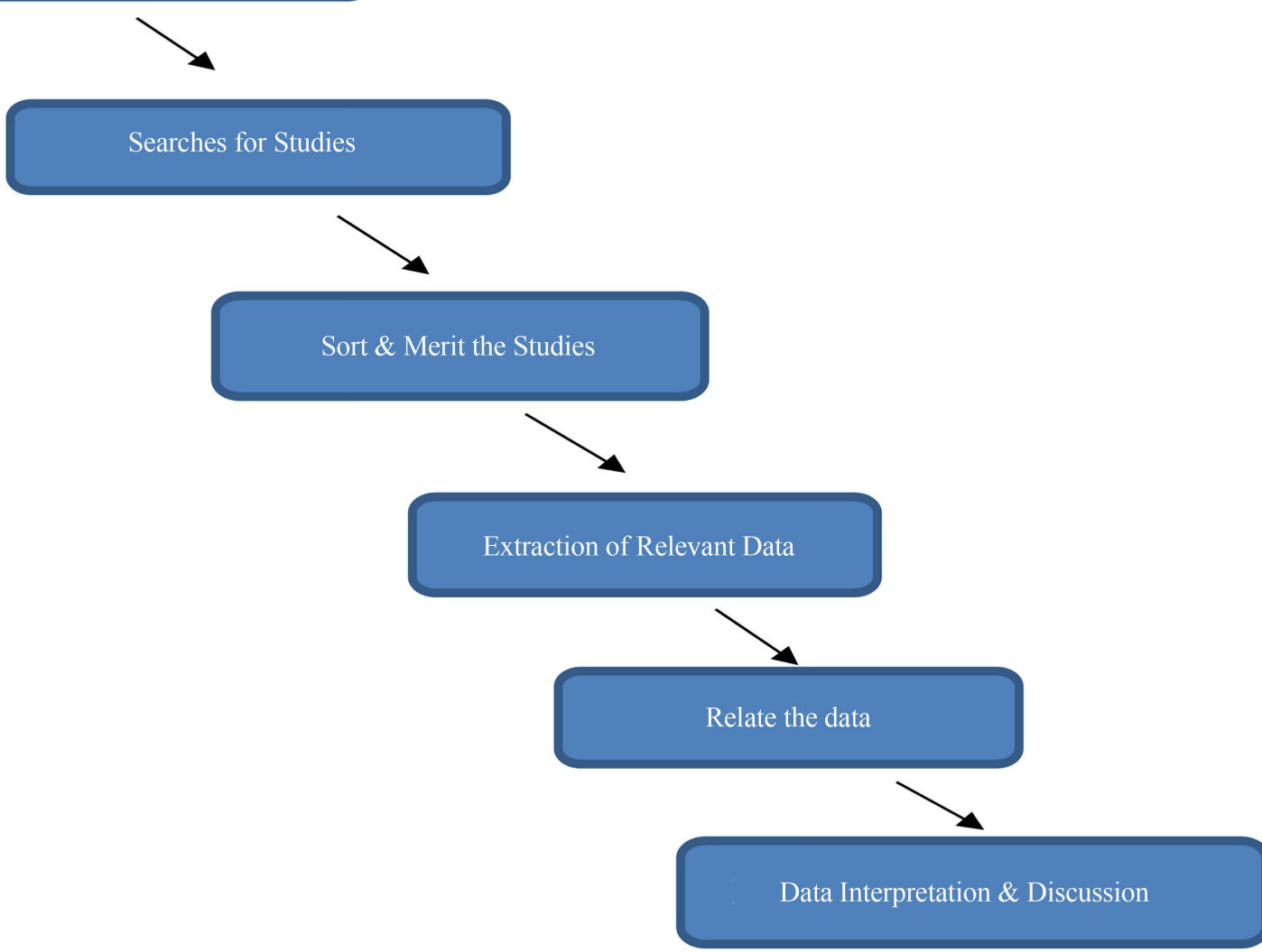

Figure 1. Procedural process flow of relevant data. 
Table 1. Source: Author's review from the literature (2021).

\begin{tabular}{cl}
\hline Relationships & \multicolumn{1}{c}{ Authors } \\
\hline Corporate Social & Phillips et al., (2019); Frederick (1983); \\
Responsibility and & Luo \& Bhattacharya (2006); Sen \& Bhattacharya (2001); \\
Customer Satisfaction & Hassan et al., (2013); Angelia \& Suryaningsih (2015); \\
& Islam et al., (2021); Latif et al., (2020); Ali et al., (2021). \\
& Suki et al., (2016); Chung et al., (2015); \\
Corporate Social & Yusof et al., (2015); Weber (2008); \\
Responsibility and & Arikan \& Güner (2013); \\
Corporate Image & Ali (2018); Del-Castillo-Feito et al., (2019). \\
& Bhatti et al., (2018); Singh \& Misra (2021); \\
Corporate Social & Lee et al., (2019); Yoo et al., (2015); \\
Responsibility and & Nyadzayo \& Khajehzadeh (2016); \\
Customer Loyalty & Rychalski \& Hudson (2017); Muflih (2021); \\
& Bukhari et al., (2020). \\
Corporate Social & Jackson \& Hua (2009); Luo \& Bhattacharya (2006); \\
Responsibility and & Mittal \& Sandhu (2018); Oyewumi et al., (2018); \\
Market Value & Yu et al., (2020); Que et al., (2019); \\
Performance & Mitra (2021); Yazid (2020). \\
\hline
\end{tabular}

\section{Discussion}

Throughout the literature, firms embarking on CSR activities have contributed to societal welfare and improved the company's market value, corporate image, and reputation in the long term through customer satisfaction (Hunjra et al., 2020). Proactiveness in the area of environmental, regulations, and social issues create a mutual relationship between firms and the major stakeholders' and therefore discloses related information to them (Freeman, 1984). Moreover, the companies that invest in corporate social responsibility create mutual understanding between the stakeholders and enjoy needed recognition, thereby enhancing corporate image and customer satisfaction (Nyadzayo \& Khajehzadeh, 2016; Latif et al., 2020). From a customer loyalty perspective, firms with CSR as a strategic marketing approach enjoy long-term and positive bottom-line benefits (Yusof et al., 2015).

As indicated by García-Madariaga \& Rodríguez-Rivera, (2017), CSR initiatives lead to companies' better financial performance and customer satisfaction. From the study, (Bukhari et al., 2020; Harun et al., 2020) stated that the banking system plays a significant role in social and economic development and CSR initiatives address social issues. They stress that there is increasing evidence that banks are embracing corporate social responsibility into their business strategy. In the context of the hotel industry, the literature provided empirical evidence and theories emphasizing that initiatives of CSR activities affect consumers' evaluation, customer satisfaction and loyalty (Agyabeng-Mensah et al., 2020; Mohammed \& Rashid, 2018; Yu et al., 2020). 
The study reviewed the relationship between customer satisfaction, corporate image, customer loyalty, and market value performance. Most literature reviewed shows that CSR and customer satisfaction and corporate image have positive relationships (Que et al., 2019; Lee et al., 2019; Avram \& Avasilcai, 2014; Yusof et al., 2015). Other studies also revealed that variables affect the relationship between CSR and customer loyalty and market value (Abdelnur, 2021; CreixansTenas et al., 2019; Mousiolis \& Zaridis, 2014). On a contrary, CSR has a limited long-term effect on financial performance, customer satisfaction and corporate image (Ali et al., 2021; Aminudin, 2013; Del-Castillo-Feito et al., 2019; Lee \& Kim, 2017; Wai Lai, 2019).

\section{Conclusion}

In this paper, we present a literature review of the studies that have investigated some effects of customer satisfaction, corporate image, customer loyalty and market value performance associated with organizations' CSR business strategy. The study shows that studies related to corporate social responsibility have evolved and covered a wide variety of topics corporate image, customer loyalty and market value performance.

The findings of this research study have theoretical contributions. First, firms with effective CSR strategies are enticed and attracted to customers. Moreover, in the banking and airline industries, CSR is a significant factor for customer satisfaction and for business existence (Bhatti et al., 2018; Lee et al., 2019). Secondly, with the application of Carroll's CSR dimensions, companies produce environmentally-friendly products taking into consideration the society (Abdullah et al., 2016). Corporate Social Responsibility as a key factor has shown a positive impact on customer loyalty as it influences the consumers to repeat purchases and customer satisfaction (Arıkan \& Güner, 2013; Carroll \& Shabana, 2010). Finally, the study revealed the relationship between CSR and financial performance, market value, company image, and reputation in different industries and suggested the implementation and integration of the concept into business strategy to maintain mutual stakeholders' interest. Further, making CSR comprehensive to capture all the initiatives is significant and a study on the effects of CSR on all the stakeholders is necessary for further research.

\section{Conflicts of Interest}

The authors declare no conflicts of interest regarding the publication of this paper.

\section{References}

Abdelnur, O. A. O. (2021). Corporate Social Responsibility Disclosure by Sudanese Listed Commercial Bank. International Review of Management and Marketing, 11, 60-67. https://doi.org/10.32479/irmm.11097

Abdullah, M. A., Chew, B. C., \& Hamid, S. R. (2016). Benchmarking Key Success Factors 
for the Future Green Airline Industry. Procedia-Social and Behavioral Sciences, 224, 246-253. https://doi.org/10.1016/j.sbspro.2016.05.456

Agyabeng-Mensah, Y., Ahenkorah, E., Afum, E., Nana Agyemang, A., Agnikpe, C., \& Rogers, F. (2020). Examining the Influence of Internal Green Supply Chain Practices, Green Human Resource Management and Supply Chain Environmental Cooperation on Firm Performance. Supply Chain Management: An International Journal, 25, 585-599. https://doi.org/10.1108/SCM-11-2019-0405

Akben-Selcuk, E. (2019). Corporate Social Responsibility and Financial Performance: The Moderating Role of Ownership Concentration in Turkey. Sustainability, 11, Article No. 3643. https://doi.org/10.3390/su11133643

Alam, N., \& Rubel, A. K. (2014). Impacts of Corporate Social Responsibility on Customer Satisfaction in Telecom Industry of Bangladesh. ABC Journal of Advanced Research, 3, 26-37.

Ali, M. (2018). Impact of Corporate Governance on Firm s Financial Performance (A Comparative Study of Developed and Non-Developed Markets). Journal of Business Management and Economic Research, 2, 15-30.

Ali, W., Danni, Y., Latif, B., Kouser, R., \& Baqader, S. (2021). Corporate Social Responsibility and Customer Loyalty in Food Chains-Mediating Role of Customer Satisfaction and Corporate Reputation. Sustainability, 13, Article No. 8681.

https://doi.org/10.3390/su13168681

Alrowais, S. S., Chapple, W., Abdel Wahab, M. S. T., \& Aboul-Dahab, S. A. M. M. (2020). The Effects of CSR on Tourist Loyalty toward Rural Hospitality Enterprises and the Moderating Effects of Religiosity. International Journal of Customer Relationship Marketing and Management, 11, 39-59.

Aminudin, N. (2013). Corporate Social Responsibility and Employee Retention of 'Green' Hotels. Procedia-Social and Behavioral Sciences, 105, 763-771. https://doi.org/10.1016/j.sbspro.2013.11.079

Angelia, D., \& Suryaningsih, R. (2015). The Effect of Environmental Performance and Corporate Social Responsibility Disclosure towards Financial Performance (Case Study to Manufacture, Infrastructure, And Service Companies That Listed at Indonesia Stock Exchange). Procedia-Social and Behavioral Sciences, 211, 348-355. https://doi.org/10.1016/j.sbspro.2015.11.045

Arıkan, E., \& Güner, S. (2013). The Impact of Corporate Social Responsibility, Service Quality and Customer-Company Identification on Customers. Procedia-Social and Behavioral Sciences, 99, 304-313. https://doi.org/10.1016/j.sbspro.2013.10.498

Avram, E., \& Avasilcai, S. (2014). Business Performance Measurement in Relation to Corporate Social Responsibility: A Conceptual Model Development. Procedia-Social and Behavioral Sciences, 109, 1142-1146. https://doi.org/10.1016/j.sbspro.2013.12.601

Bhatti, A., Arif, S., Marium, M., \& Younas, S. (2018). The Impact of Corporate Social Responsibility (CSR) and Relationship Marketing on Relationship Maintainer and Customer Loyalty by Mediating Role of Customer Satisfaction. Journal of Management Info, 4, 19-24.

Brown, J. \& Forster, W. R. (2013). CSR and Stakeholder Theory: A Tale of Adam Smith. Journal of Business Ethics, 112, 301-312. https://doi.org/10.1007/s10551-012-1251-4

Bukhari, S. A. A., Hashim, F., \& Amran, A. B. (2020). Determinants and Outcome of Islamic Corporate Social Responsibility (ICSR) Adoption in Islamic Banking Industry of Pakistan. Journal of Islamic Marketing, 12, 730-762.

https://doi.org/10.1108/JIMA-11-2019-0226 
Capozzi, M. M., Gregg, B., \& Howe, A. (2010). Innovation and Commercialization. McKinsey Global and Financial Survey Results. McKinsey \& Company.

Carroll, A. B., \& Shabana, K. M. (2010). The Business Case for Corporate Social Responsibility: A Review of Concepts, Research and Practice. International Journal of Management Reviews, 12, 85-105. https://doi.org/10.1111/j.1468-2370.2009.00275.x

Chung, K. H., Yu, J. E., Choi, M. G., \& Shin, J. I. (2015). The Effects of CSR on Customer Satisfaction and Loyalty in China: The Moderating Role of Corporate Image. Journal of Economics, Business and Management, 3, 542-547. https://doi.org/10.7763/JOEBM.2015.V3.243

Crane, A., McWilliams, A., Matten, D., Moon, J., \& Seigel, D. S. (2008). The Oxford Handbook of Corporate Social Responsibility. Journal of European Industrial Training, 35, 108-111.

Creixans-Tenas, J., Coenders, G., \& Arimany-Serrat, N. (2019). Corporate Social Responsibility and Financial Profile of Spanish Private Hospitals. Heliyon, 5, E02623. https://doi.org/10.1016/j.heliyon.2019.e02623

Darus, F., Hamzah, E. A. C. K., \& Yusoff, H. (2013). CSR Web Reporting: The Influence of Ownership Structure and Mimetic Isomorphism. Procedia Economics and Finance, 7, 236-242. https://doi.org/10.1016/S2212-5671(13)00240-2

Del-Castillo-Feito, C., Blanco-Gonzalez, A., \& Gonzalez-Vazquez, E. (2019). The Relationship between Image and Reputation in the Spanish Public University. European Research on Management and Business Economics, 25, 87-92.

https://doi.org/10.1016/j.iedeen.2019.01.001.

Frederick, W. C. (1983). Point of View: Corporate Social Responsibility in the Reagan Era and beyond. California Management Review, 25, 145-157.

https://doi.org/10.2307/41165022

Freeman, R. E. (1984). Strategic Management: A Stakeholder Approach. Pitman, Boston.

García-Madariaga, J., \& Rodríguez-Rivera, F. (2017). Corporate Social Responsibility, Customer Satisfaction, Corporate Reputation, and Firms' Market Value: Evidence from the Automobile Industry. Spanish Journal of Marketing, 21, 39-53.

https://doi.org/10.1016/j.sjme.2017.05.003

Goundar, S. (2012). Chapter 3: Research Methodology and Research Method. In S. Goundar (Ed.), Cloud Computing. Research Gate Publications.

Harun, M. S., Hussainey, K., Mohd Kharuddin, K. A., \& Al Farooque, O. (2020). CSR Disclosure, Corporate Governance and Firm Value: A Study on GCC Islamic Banks. International Journal of Accounting \& Information Management, 28, 607-638. https://doi.org/10.1108/IJAIM-08-2019-0103

Hassan, Z., Nareeman, A., \& Pauline, N. (2013). Impact of CSR Practices on Customer Satisfaction and Retention: An Empirical Study on Foreign MNCs in Malaysia. International Journal of Accounting and Business Management, 1, 63-81. https://doi.org/10.2139/ssrn.2327243

Hunjra, A. I., Verhoeven, P., \& Zureigat, Q. (2020). Capital Structure as a Mediating Factor in the Relationship between Uncertainty, CSR, Stakeholder Interest and Financial Performance. Journal of Risk and Financial Management, 13, Article No. 117. https://doi.org/10.3390/jrfm13060117

Islam, T., Islam, R., Pitafi, A. H., Xiaobei, L., Rehmani, M., Irfan, M., \& Mubarak, M. S. (2021). The Impact of Corporate Social Responsibility on Customer Loyalty: The Mediating Role of Corporate Reputation, Customer Satisfaction, and Trust. Sustainable Production and Consumption, 25, 123-135. https://doi.org/10.1016/j.spc.2020.07.019 
Jackson, L. A. \& Hua, N. (2009). Corporate Social Responsibility and Financial Performance: A Snapshot from the Lodging and Gaming Industries. The Journal of Hospitality Financial Management, 17, 63-78. https://doi.org/10.1080/10913211.2009.10653871

Keller, K. L. (2003). Understanding Brands, Branding and Brand Equity. Interactive Marketing, 5, 7-20. https://doi.org/10.1057/palgrave.im.4340213

Kotler, P., \& Barich, H. (1991). A Framework for Marketing Image Marketing Image Management. Sloan Management Review, 32, 94-104.

Latapí Agudelo, M. A., Jóhannsdóttir, L., \& Davídsdóttir, B. (2019). A Literature Review of the History and Evolution of Corporate Social Responsibility. International Journal of Corporate Social Responsibility, 4, Article No. 1.

https://doi.org/10.1186/s40991-018-0039-y

Latif, K. F., Pérez, A., \& Sahibzada, U. F. (2020). Corporate Social Responsibility (CSR) and Customer Loyalty in the Hotel Industry: A Cross-Country Study. International Journal of Hospitality Management, 89, Article ID: 102565.

https://doi.org/10.1016/j.ijhm.2020.102565

Lee, J., \& Kim, E. (2017). CSR Report as a Buffer: Mitigating a Negative Effect of CSR Performance on Short-term Financial Performance. Korean Management Review, 46, 1343-1365. https://doi.org/10.17287/kmr.2017.46.5.1343

Lee, S. S., Kim, Y., \& Roh, T. (2019). Modified Pyramid of CSR for Corporate Image and Customer Loyalty: Focusing on the Moderating Role of the CSR Experience. Sustainability, 11, Article No. 4745. https://doi.org/10.3390/su11174745

Lee, S., \& Yoon, J. (2018). Does the Authenticity of Corporate Social Responsibility Affect Employee Commitment? Social Behavior and Personality: An International Journal, 46, 617-632. https://doi.org/10.2224/sbp.6475

Lemon, K. N., White, T. B., \& Winer, R. S. (2002). Dynamic Customer Relationship Management: Incorporating Future Considerations into the Service Retention Decision. Journal of Marketing, 66, 1-14.

Luo, X., \& Bhattacharya, C. B. (2006). Corporate Social Responsibility, Customer Satisfaction, and Market Value. Journal of Marketing, 70, 1-18. https://doi.org/10.1509/jmkg.70.4.001

Maignan, I., \& Ferrell, O. C. (2004). Corporate Social Responsibility and Marketing: An Integrative Framework. Journal of the Academy of Marketing Science, 32, 3-19.

Manhas, P. S., \& Tukamushaba, E. K. (2015). Understanding Service Experience and Its Impact on Brand Image in Hospitality Sector. International Journal of Hospitality Management, 45, 77-87. https://doi.org/10.1016/j.ijhm.2014.11.010

Mensah, H. K., Agyapong, A., \& Nuertey, D. (2017). The Effect of Corporate Social Responsibility on Organizational Commitment of Employees of Rural and Community Banks in Ghana. Cogent Business \& Management, 4, Article ID: 1280895. https://doi.org/10.1080/23311975.2017.1280895

Mitra, N. (2021). Impact of Strategic Management, Corporate Social Responsibility on Firm Performance in the Post Mandate Period: Evidence from India. International Journal of Corporate Social Responsibility, 6, 1-15.

Mittal, A., \& Sandhu, N. (2018). To Investigate the Relationship between CSR of Companies and Their Market Valuation (Equity Valuation): Northern India. Journal of Advances and Scholarly Researches in Allied Education, 15, 120-127. https://doi.org/10.29070/15/57254

Mohammed, A., \& Rashid, B. (2018). A Conceptual Model of Corporate Social Responsibility Dimensions, Brand Image, and Customer Satisfaction in Malaysian Hotel Indus- 
try. Kasetsart Journal of Social Sciences, 39, 358-364.

https://doi.org/10.1016/j.kjss.2018.04.001

Mohr, L. A. et al. (2001). Do Consumers Expect Companies to Be Socially Responsible? The Impact of Corporate Social Responsibility on Buying Behavior. Journal of Consumer Affairs, 35, 45-72. https://doi.org/10.1111/j.1745-6606.2001.tb00102.x

Mousiolis, D. T., \& Zaridis, A. D. (2014). The Effects in the Structure of an Organization through the Implementation of Policies from Corporate Social Responsibility (CSR). Procedia-Social and Behavioral Sciences, 148, 634-638. https://doi.org/10.1016/j.sbspro.2014.07.091

Muflih, M. (2021). The Link between Corporate Social Responsibility and Customer Loyalty: Empirical Evidence from the Islamic Banking Industry. Journal of Retailing and Consumer Services, 61, Article ID: 102558. https://doi.org/10.1016/j.jretconser.2021.102558

Nyadzayo, M. W., \& Khajehzadeh, S. (2016). The Antecedents of Customer Loyalty: A Moderated Mediation Model of Customer Relationship Management Quality and Brand Image. Journal of Retailing and Consumer Services, 30, 262-270. https://doi.org/10.1016/j.jretconser.2016.02.002

Nyeadi, J. D., Ibrahim, M., \& Sare, Y. A. (2018). Corporate Social Responsibility and Financial Performance Nexus. Journal of Global Responsibility, 9, 301-328. https://doi.org/10.1108/JGR-01-2018-0004

Okoe, A. F., \& Boateng, H. (2015). Consumer Attitudes toward and Intentions to Accept Mobile Advertising. Management Science Letters, 5, 833-842. https://doi.org/10.5267/j.msl.2015.7.002

Oliver, R. L. (1980). A Cognitive Model of the Antecedents and Consequences of Satisfaction Decisions. Journal of Marketing Research, 17, 460-469.

Oyewumi, O. R., Ogunmeru, O. A., \& Oboh, C. S. (2018). Investment in Corporate Social Responsibility, Disclosure Practices, and Financial Performance of Banks in Nigeria. Future Business Journal, 4, 195-205. https://doi.org/10.1016/j.fbj.2018.06.004

Pearce, J., \& Doh, J. (2005). The High Impact of Collaborative Social Initiatives. MIT Sloan Management Review, 46, 30-39.

Phillips, S., Thai, V. V., \& Halim, Z. (2019). Airline Value Chain Capabilities and CSR Performance: The Connection between CSR Leadership and CSR Culture with CSR Performance, Customer Satisfaction and Financial Performance. The Asian Journal of Shipping and Logistics, 35, 30-40. https://doi.org/10.1016/j.ajsl.2019.03.005

Que, S., Wang, L., Awuah-Offei, K., Yang, W., \& Jiang, H. (2019). Corporate Social Responsibility: Understanding the Mining Stakeholder with a Case Study. Sustainability, 11, Article No. 2407. https://doi.org/10.3390/su11082407

Reza, S., Mubarik, M. S., Naghavi, N., \& Rub Nawaz, R. (2020). Relationship Marketing and Third-Party Logistics: Evidence from Hotel Industry. Journal of Hospitality and Tourism Insights, 3, 371-393. https://doi.org/10.1108/JHTI-07-2019-0095

Rychalski, A., \& Hudson, S. (2017). Asymmetric Effects of Customer Emotions on Satisfaction and Loyalty in a Utilitarian Service Context. Journal of Business Research, 71, 84-91. https://doi.org/10.1016/j.jbusres.2016.10.014

Sen, S., \& Bhattacharya, C. B. (2001). Does Doing Good Always Lead to Doing Better? Consumer Reactions to Corporate Social Responsibility. Journal of Marketing Research, 38, 225-243. https://doi.org/10.1509/jmkr.38.2.225.18838

Sharma, K. (2020). Relationship between Corporate Social Responsibility and Financial 
Performance: A study on Indian Banking Sector. International Journal for Research in Applied Science and Engineering Technology, 8, 1125-1135.

https://doi.org/10.22214/ijraset.2020.31698.

Singh, K., \& Misra, M. (2021). Linking Corporate Social Responsibility (CSR) and Organizational Performance: The Moderating Effect of Corporate Reputation. European Research on Management and Business Economics, 27, Article ID: 100139. https://doi.org/10.1016/j.iedeen.2020.100139

Suki, N. M., Suki, N. M., \& Azman, N. S. (2016). Impacts of Corporate Social Responsibility on the Links between Green Marketing Awareness and Consumer Purchase Intentions. Procedia Economics and Finance, 37, 262-268. https://doi.org/10.1016/S2212-5671(16)30123-X

Velte, P. (2021). Meta-Analyses on Corporate Social Responsibility (CSR): A Literature Review. Management Review Quarterly. https://doi.org/10.1007/s11301-021-00211-2

Wai Lai, I. K. (2019). Hotel Image and Reputation on Building Customer Loyalty: An Empirical Study in Macau. Journal of Hospitality and Tourism Management, 38, 111-121. https://doi.org/10.1016/j.jhtm.2019.01.003

Weber, M. (2008). The Business Case for Corporate Social Responsibility: A Company-Level Measurement Approach for CSR. European Management Journal, 26, 247-261. https://doi.org/10.1016/j.emj.2008.01.006

Yazid, A. S. (2020). The Mediating Effect of Customer Satisfaction on the Relationship between Corporate Social Responsibility and Customer Loyalty. Journal of Advanced Research in Dynamical and Control Systems, 24, 299-309.

https://doi.org/10.5373/jardcs/v12i4/20201444

Yoo, S. J., Huang, W. H. D., \& Kwon, S. (2015). Gender Still Matters: Employees' Acceptance Levels towards E-Learning in the Workplaces of South Korea. Knowledge Management \& E-Learning: An International Journal, 7, 334-347.

https://doi.org/10.34105/j.kmel.2015.07.021

Yu, J., Jiang, C., Zhuang, X., Na, S., \& Cui, Z. (2020). The Formation Mechanism of Consumer Perceived Corporate Social Responsibility Authenticity: An Empirical Study of Chinese Consumers. Sustainability, 12, Article No. 2479.

https://doi.org/10.3390/su12062479

Yusof, J. M., Manan, H. A., Karim, N. A., \& Kassim, N. A. M. (2015). Customer's Loyalty Effects of CSR Initiatives. Procedia-Social and Behavioral Sciences, 170, 109-119. https://doi.org/10.1016/j.sbspro.2015.01.020 